\title{
Metode SURF dan FLANN untuk Identifikasi Nominal Uang Kertas Rupiah Tahun Emisi 2016 pada Variasi Rotasi
}

\author{
Identification of Rupiah Paper Currency Denomination using SURF and FLANN \\ Methods at Rotation Variation
}

\author{
Adri Priadana ${ }^{*, 1)}$, Aris Wahyu Murdiyanto ${ }^{2)}$ \\ ${ }^{1)}$ Program Studi Teknik Informatika, Universitas Jenderal Achmad Yani Yogyakarta \\ Jl. Siliwangi, Ringroad Barat, Banyuraden, Gamping, Sleman, Daerah Istimewa Yogyakarta, Indonesia 55293 \\ ${ }^{2)}$ Program Studi Sistem Informasi, Universitas Jenderal Achmad Yani Yogyakarta \\ Jl. Siliwangi, Ringroad Barat, Banyuraden, Gamping, Sleman, Daerah Istimewa Yogyakarta, Indonesia 55293
}

Cara sitasi: A. Priadana and A. W. Murdiyanto, "Metode SURF dan FLANN untuk Identifikasi Nominal Uang Kertas Rupiah Tahun Emisi 2016 pada Variasi Rotasi," Jurnal Teknologi dan Sistem Komputer, vol. 7 no. $1,2019$. doi: 10.14710/jtsiskom.7.1.2019.19-24, [Online].

\begin{abstract}
In December 2016, Bank Indonesia (BI) officially launched the 2016 Year Emission Rupiah. With the development of technology, the process of buying and selling are not only possible between humans and humans, but humans with a machine. In addition, the machine must also be able to read and recognize the nominal banknotes in various variations of face and rotation. This is because humans can put money in machines with various variations of face and rotation. This study aims to apply and analyze the level of accuracy of nominal rupiah banknotes identification with the SURF and FLANN methods for rotation variation. Testing for identification of nominal rupiah banknotes is carried out with different rotation variations, namely $0^{\circ}, 90^{\circ}, 180^{\circ}$, and $270^{\circ}$. The proposed identification method provides $100 \%$ of accuracy.
\end{abstract}

Keywords - identification of nominal banknotes; feature extraction; SURF; feature matching; FLANN

Abstrak - Pada bulan Desember 2016, Bank Indonesia (BI) secara resemi meluncurkan uang rupiah Emisi 2016. Semakin berkembangnya teknologi, saat ini proses jual beli tidak hanya dapat dilakukan antara manusia dengan manusia, akan tetapi manusia dengan mesin. Selain itu mesin juga harus dapat membaca dan mengenali nominal uang kertas dalam berbagai variasi muka dan rotasi. Hal ini dikarenakan manusia dapat memasukkan uang pada mesin dengan berbagai variasi muka dan rotasi. Penelitian ini bertujuan untuk menerapkan dan menganalisis tingkat akurasi identifikasi nominal uang kertas rupiah dengan metode SURF dan FLANN terhadap variasi rotasi. Pengujian identifikasi uang nominal uang kertas rupiah dilakukan dengan variasi rotasi yang berbeda yaitu $0^{\circ}, 90^{\circ}, 180^{\circ}$, dan $270^{\circ}$. Metode

\footnotetext{
${ }^{*}$ Penulis korespondensi (Adri Priadana)

Email: adripriadana3202@gmail.com
}

identifikasi yang diajukan memberikan hasil akurasi sebesar $100 \%$.

Kata Kunci - identifikasi nominal uang kertas; ekstraksi ciri; SURF; feature matching; FLANN

\section{Pendahuluan}

Rupiah merupakan mata uang negara Indonesia. Bank Indonesia menjadi satu-satunya lembaga yang berwenang melakukan pengeluaran, pengedaran dan atau pencabutan rupiah. Tampilan uang Rupiah sendiri selalu berubah dari waktu ke waktu. Pada bulan Desember 2016, Bank Indonesia (BI) secara resmi meluncurkan uang rupiah Emisi 2016 dengan gambar pahlawan baru. Peluncuran uang rupiah baru ini dilakukan langsung oleh Presiden RI Joko Widodo. Uang rupiah baru yang diluncurkan tersebut terdiri atas tujuh pecahan uang rupiah kertas dan empat pecahan uang rupiah logam. Uang rupiah baru ini akan menampilkan 12 gambar pahlawan nasional.

Setiap uang memiliki nilai nominal yang berguna untuk menentukan nilai dari suatu barang dan jasa yang diperjualbelikan. Pada proses jual beli konvensional pastinya akan terjadi pertemuan antara penjual dan pembeli. Semakin berkembangnya teknologi, saat ini proses jual beli tidak hanya dapat dilakukan antara manusia dengan manusia, akan tetapi manusia dengan mesin. Proses jual beli tersebut hanya melibatkan manusia sebagai pembeli dan mesin sebagai penjual dengan tetap menggunakan uang sebagai alat pembayarannya. Jika ingin mendukung proses jual beli antara manusia dengan mesin, maka mesin sebagai penjual harus bisa membaca dan mengenali setiap nominal uang seperti yang dilakukan oleh manusia. Selain itu, mesin juga harus dapat membaca dan mengenali nominal uang kertas dalam berbagai variasi muka dan rotasi. Hal ini disebabkan manusia dapat memasukkan uang pada mesin dengan berbagai variasi muka dan rotasi. 


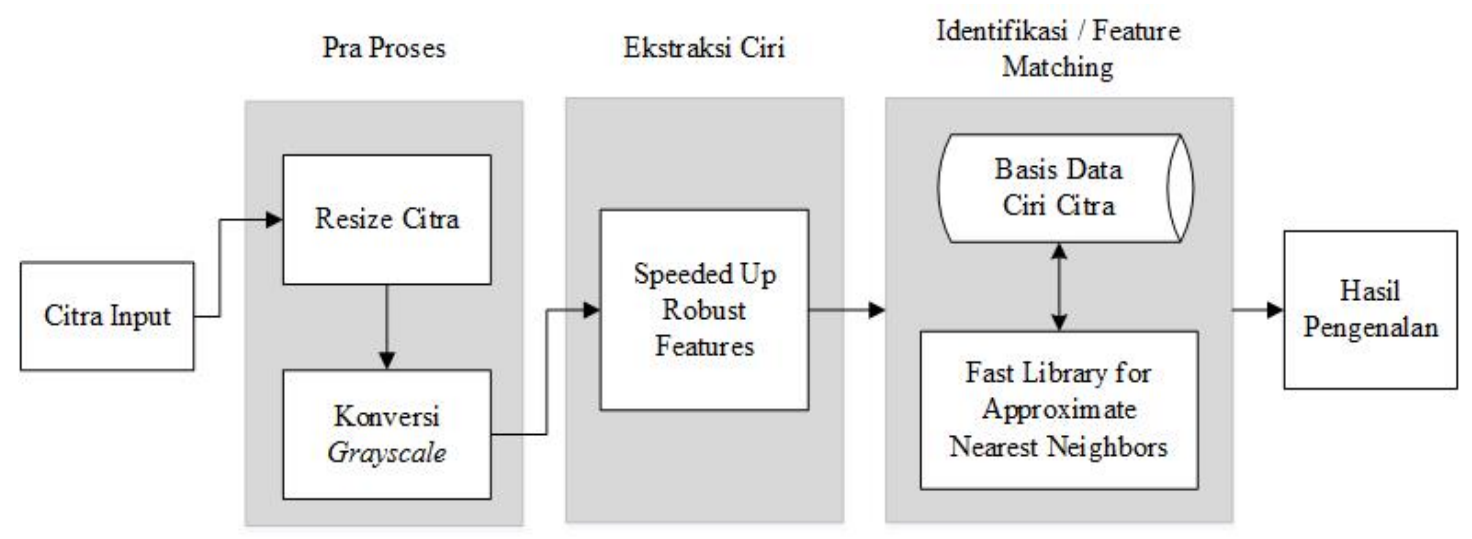

Gambar 1. Urutan proses sistem identifikasi nominal uang kertas rupiah

Berdasarkan hal tersebut, maka dibutuhkan suatu sistem yang dapat mengenali atau mengidentifikasi nominal uang kertas rupiah dalam berbagai variasi muka dan rotasi secara cepat dan tepat seperti yang dilakukan oleh manusi sehingga proses jual beli yang melibatkan manusia sebagai pembeli dan mesin sebagai penjual dapat berjalan dengan baik. Proses identifikasi uang kertas dapat dilakukan dengan klasifikasi citra nominal uang kertas untuk menemukan model yang dapat membedakan kelas data. Klasifikasi ini bertujuan untuk dapat memperkirakan kelas dari suatu objek yang labelnya tidak diketahui.

Bidang teknologi yang dapat merealisasikan hal tersebut adalah pengolahan citra dan kecerdasan buatan. Metode Speed Up Robust Feature (SURF) merupakan salah satu metode yang digunakan untuk mengekstraksi ciri dari sebuah citra. Metode SURF telah banyak digunakan untuk mengekstraksi ciri dari sebuah citra untuk kebutuhan identifikasi [1]-[6].

Sistem untuk melakukan klasifikasi nominal uang kertas telah banyak dilakukan. Hikmayanti dan Komarudin [7] mengembangkan identifikasi nominal uang kertas dengan algoritma backpropagation Levenberg Marquardt. Tingkat akurasi yang didapatkan dengan metode yang digunakan untuk mendeteksi nominal uang kertas adalah sebesar 50\%. Saputra dkk. [8] menerapkan metode Jaringan Syaraf Tiruan (JST) pada alat deteksi nilai nominal uang. Dari hasil 20 kali pengujian alat menggunakan kombinasi beberapa pecahan uang, akurasi yang dihasilkan adalah sebesar 90\%. Penelitian lain yang berkaitan dengan identifikasi nominal uang kertas rupiah adalah penelitian yang menerapkan algoritma Convolutional Neural Network menggunakan MXNET untuk klasifikasi nominal uang kertas rupiah tahun emisi 2017 [9]. Penelitian tersebut memperoleh akurasi sebesar $100 \%$ untuk data train dan 93,57\% untuk data test.

Penelitian tersebut di atas tidak membahas bagaimana sistem yang telah dibuat dapat mengidentifikasi nominal uang kertas dengan berbagai variasi muka dan rotasi. Padahal dalam [10] metode SURF dapat digunakan untuk melakukan ekstraksi ciri yang salah satunya memiliki ketahanan. Metode SURF belum pernah diterapkan dan dianalisis untuk mengekstraksi ciri citra nominal uang kertas rupiah tahun emisi 2016. Penelitian ini bertujuan untuk menerapkan dan menganalisis tingkat akurasi identifikasi nominal uang kertas rupiah tahun emisi 2016 dengan metode SURF dan FLANN terhadap variasi rotasi. Akurasi identifikasi diuji dengan memutar uang kertas $0^{\circ}, 90^{\circ}, 180^{\circ}$, dan $270^{\circ}$.

\section{Metode Penelitian}

Tahapan penelitian yang dilakukan dalam penelitian ini terdiri atas pengumpulan data, perancangan sistem, dan pengujian sistem.

\section{A. Pengumpulan Data}

Data yang digunakan untuk mendukung penelitian ini adalah semua citra uang kertas rupiah tahun emisi 2016 pecahan Rp 1.000,00, Rp 2.000,00, Rp 5.000,00, Rp 10.000,00, Rp 20.000,00, Rp 50.000,00 dan Rp 100.000,00.

\section{B. Perancangan Sistem}

Proses identifikasi pada sistem ini terbagi atas tiga bagian utama, yaitu praproses, ekstraksi ciri dan proses identifikasi (feature matching). Secara umum urutan proses dari sistem identifikasi nominal uang kertas rupiah ditunjukkan pada Gambar 1.

\section{Tahap Pra Proses}

Tahap pra proses pada penelitian ini terdiri dari pengaturan ulang ukuran citra (resize) dan konversi citra hasil akuisisi dari format RGB ke grayscale. Citra hasil akuisisi pertama kali akan dikenai operasi pengaturan ulang skala ke ukuran resolusi tetap yang lebih kecil yaitu 200x200 piksel. Kemudia citra akan diubah dalam mode grayscale. Dalam pengubahan citra RGB kedalam bentuk grayscale, digunakan Persamaan 1. Citra hasil konversi ke grayscale dapat dilihat pada Gambar 2.

$$
Y^{\prime}=0.299 R+0.587 G+0.114 B
$$




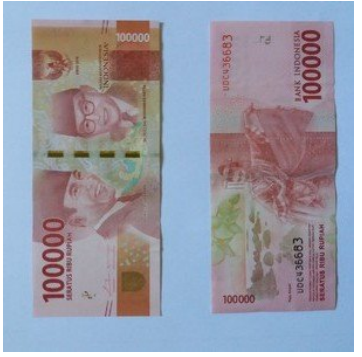

(a)

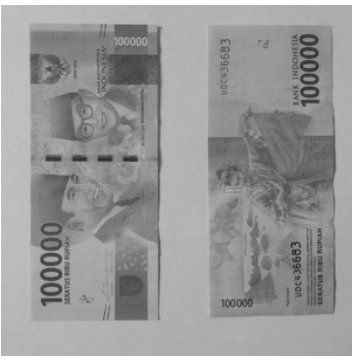

(b)
Gambar 2. Citra nominal uang kertas rupiah: a) citra input, b) citra hasil konversi ke grayscale

\section{Tahap Ekstraksi Ciri}

Metode ekstraksi ciri pada penelitian ini dilakukan dengan metode Speeded Up Robust Features (SURF). Metode ini menggunakan penggabungan algoritma integral citra dan blob detection berdasarkan determinan dari matriks Hessian. Citra input diubah ke dalam bentuk citra integral. Calon ciri pada citra dicari menggunakan matriks Hessian. Pencarian terhadap ciri dilakukan pada scale space. Hal ini dilakukan agar nilai ciri yang dihasilkan memiliki ketahanan terhadap skala.

Scale space dibentuk dengan melakukan iterasi konvolusi terhadap citra masukan dengan tapis kernel Gaussian diskret dan berulang kali melakukan subsampling yang akhirnya mereduksi ukuran citra. Piramida citra terbentuk karena dari setiap perulangan yang terjadi, ukuran citra pada scale space akan terus berkurang.

Pencarian ciri (interest point) pada scale space tersebut ditentukan berdasarkan nilai ekstremum yang merupakan hasil perbandingan nilai antar titik piksel tetangga lintas scale. Sebuah titik ditentukan sebagai interest point jika nilai perhitungan pada ekstremumnya lebih besar daripada threshold. Tahap terakhir dari proses ekstraksi ciri dengan metode SURF adalah melakukan deskripsi terhadap ciri atau interest point yang didapatkan. Pendeskripsian ini bertujuan agar interest point lebih tahan terhadap rotasi, sudut pengambilan citra dan intensitas cahaya. Hasil yang didapatkan dari tahapan ekstraksi ciri ini adalah vektor ciri yang mendeskripsikan citra itu sendiri. Secara umum urutan proses ekstraksi ciri dengan metode SURF dapat dilihat pada Gambar 3.

\section{Tahap Identifikasi (Feature Matching)}

Tahap identifikasi pada penelitian ini memanfaatkan teknik feature matching dengan memanfaatkan Fast Library for Approximate Nearest Neighbors (FLANN). Metode ini digunakan untuk melakukan pencarian perkiraan neighborhood secara cepat, yang terdapat pada ruang dimensi yang tinggi. Pustaka FLANN ini bekerja dengan baik untuk menemukan nilai tetangga terdekat.

Satu citra di basis data memiliki banyak klaster untuk vektor ciri hasil ekstraksi ciri dengan metode

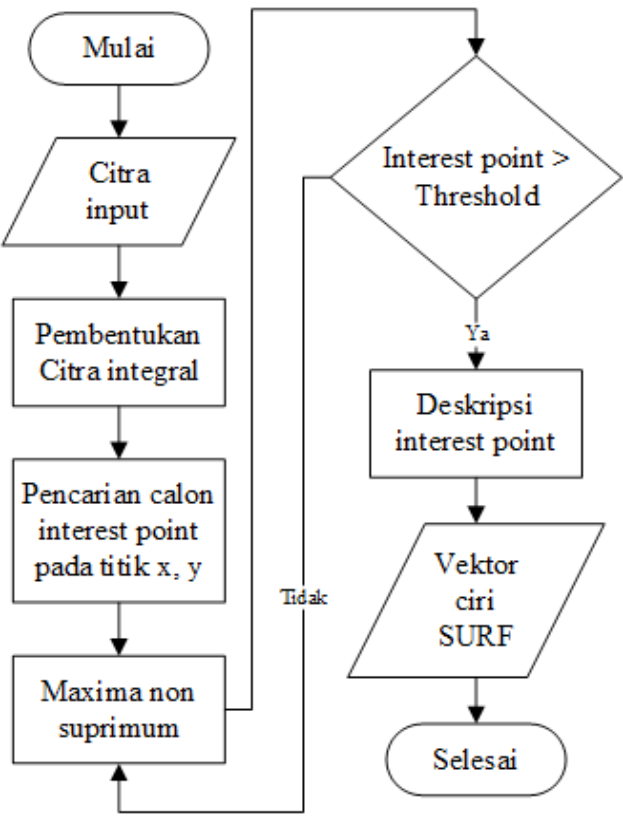

Gambar 3. Urutan proses ekstraksi ciri dengan metode SURF

SURF. Klaster ini dibuat otomatis dengan menggunakan KNN (K-Nearest Neighbor) dengan tipe indeks KD tree [10]. Proses pencocokkan ciri pada citra masukan dengan ciri pada citra dalam basis data dilakukan menggunakan KNN search. KNN search mencari klaster pada basis data yang nilai vektor deskriptornya paling dekat jaraknya dengan vektor deskriptor pada citra masukan. Setelah klaster didapat, nilai vektor deskriptor dicari pada klaster tersebut yang sama atau paling dekat dengan vektor deskriptor pada citra masukan. Jika ada yang sama, maka ada satu keypoint yang cocok antara kedua citra tersebut. Semakin banyak jumlah keypoint yang cocok, maka semakin besar nilai kecocokan antara citra masukan dengan citra pada basis data.

Sistem pada penelitian ini diterapkan dengan memanfaatkan library OpenCV yang berisi fungsifungsi pemrograman untuk teknologi computer vision dimana salah satunya adalah FLANN. Library-library pada OpenCV bersifat open source dan telah banyak digunakan pada penelitian yang mengembangkan aplikasi pengolahan citra digital [11].

\section{Pengujian Sistem}

Objek yang digunakan untuk melakukan pengujian seluruhnya berjumlah 7 buah pecahan nominal uang kertas dimana masing-masing terdiri dari dua muka. Masing-masing objek tersebut akan dikenai berbagai pengujian rotasi, yaitu tanpa rotasi atau $0^{\circ}$, rotasi $90^{\circ}$, rotasi $180^{\circ}$, dan rotasi $270^{\circ}$. Contoh citra pecahan nominal uang kertas rupiah dalam beberapa variasi rotasi tersebut dapat dilihat pada Gambar 4. Persamaan 2 digunakan untuk mengukur akurasi hasil pengenalan objek masing-masing pengujian pada setiap variasi yang ada. Secara keseluruhan, akurasi arsitektur sistem yang dibangun dihitung menggunakan Persamaan 3. 


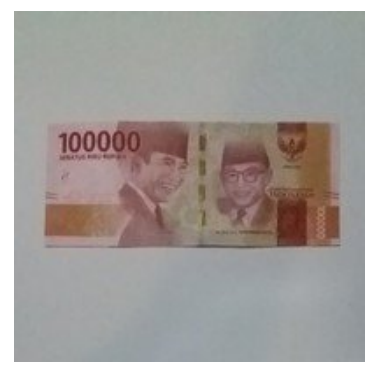

(a)

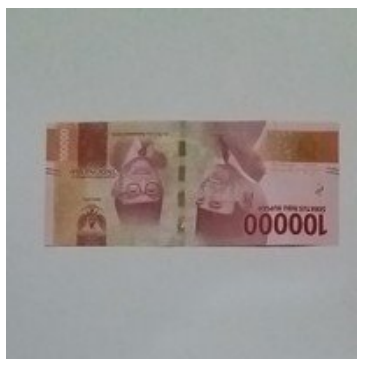

(c)

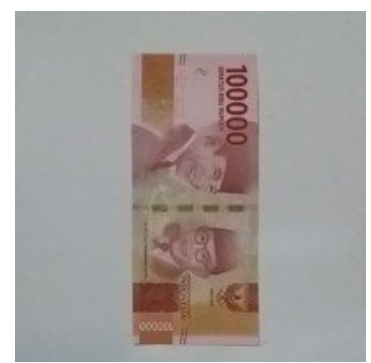

(b)

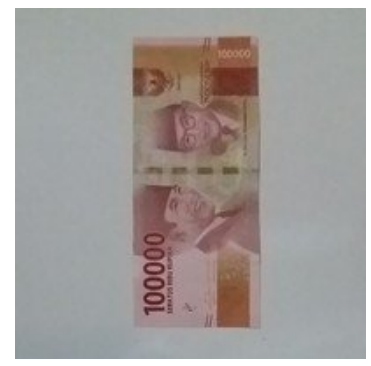

(d)
Gambar 4. Citra nominal uang kertas rupiah: a) rotasi $0^{\circ}$, b) rotasi $90^{\circ}$, c) rotasi $180^{\circ}$, dan d) rotasi $270^{\circ}$

$$
\begin{gathered}
\text { akurasi }(\text { variasi })=\frac{\sum \text { databenar }}{\sum \text { seluruhdata }} \times 100 \% \\
\operatorname{akurasi}(\text { total })=\frac{\sum \text { akurasi }(\text { variasi })}{4} \times 100 \%
\end{gathered}
$$

\section{Hasil dan Pembahasan}

Bab ini menjelaskan mengenai rangkaian uji coba dan evaluasi terhadap metode yang diimplementasikan pada penelitian ini. Tahap uji coba dilakukan untuk menguji kinerja dari sistem dan seberapa besar nilai akurasi yang dihasilkan oleh sistem. Tahap evaluasi dilakukan dengan menganalisa hasil uji coba yang telah dilakukan. Terdapat dua parameter kondisi yang diterapkan pada pengujian sistem, yaitu ketinggian kamera dan intensitas cahaya. Pada tahap pengambilan citra, ketinggian kamera dari obyek kurang lebih adalah 30CM dengan intensitas cahaya kurang lebih adalah 1000-3000Lux.

Pada tahap praproses, citra masukan mengalami operasi pengaturan ulang skala (resizing) ke ukuran yang lebih kecil yaitu menjadi 200x200 piksel. Ukuran hasil resizing pada penelitian ini tidak dilakukan sampai ke ukuran citra yang terkecil. Hal ini disebabkan semakin kecil ukuran citra hasil resizing, maka jumlah keypoint hasil ekstraksi ciri dengan metode SURF akan ikut berkurang secara signifikan sehingga mempengaruhi akurasi hasil identifikasi obyek [12]. Citra kemudian diubah dalam mode grayscale, seperti pada Gambar 2.

Pada proses ekstraksi ciri citra dengan metode SURF, diperoleh keypoint yang merupakan vektor ciri yang mendeskripsikan citra itu sendiri. Keypoint dari hasil ekstraksi ciri citra nominal uang kertas rupiah

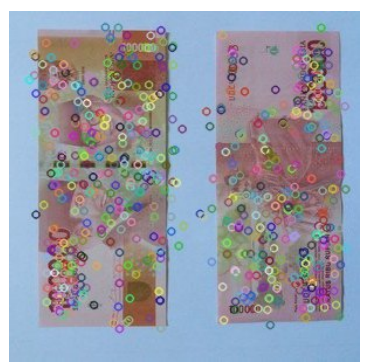

(a)

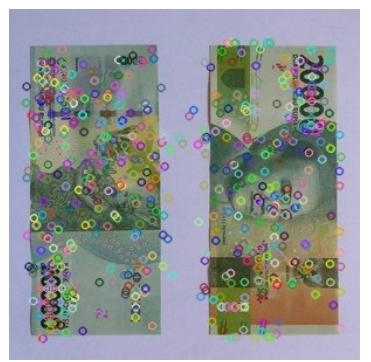

(c)

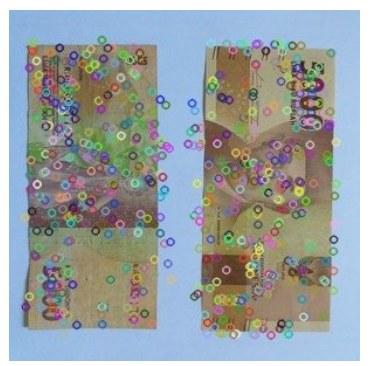

(e)

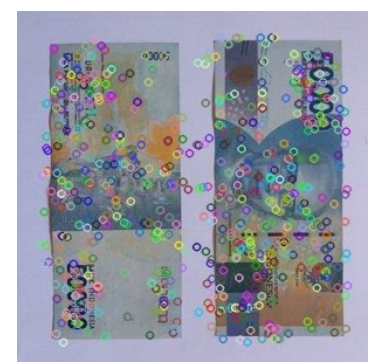

(b)

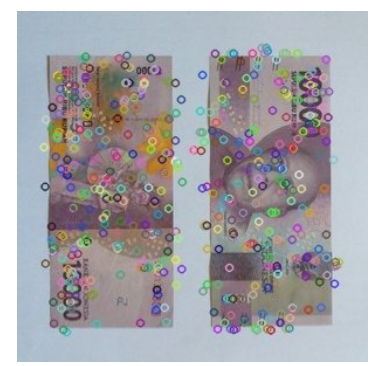

(d)

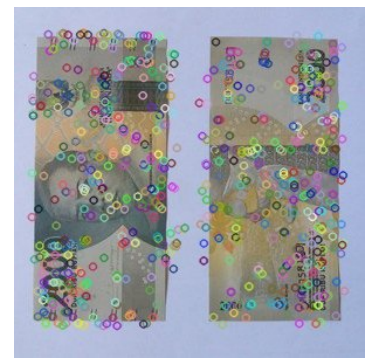

(f)

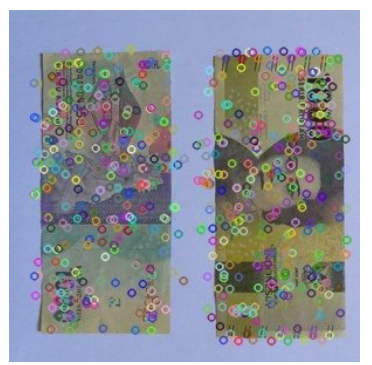

(g)

Gambar 5. Keypoint hasil ekstraksi ciri citra nominal uang kertas rupiah dengan metode SURF: a) seratus ribu, b) lima puluh ribu, c) dua puluh ribu, d) sepuluh ribu, e) lima ribu, f) dua ribu, dan g) seribu

dengan metode SURF dapat dilihat pada Gambar 5. Pada proses identifikasi dengan metode FLANN, dilakukan pencocokan vektor ciri hasil dari ekstaksi ciri dengan metode SURF pada citra masukan dengan ciri pada citra dalam basis data. Hasil identifikasi akan didasari dari jumlah nilai kecocokan terbesar antara citra masukan dengan citra pada basis data akan. Proses identifikasi dengan metode FLANN pada citra nominal uang kertas rupiah dapat dilihat pada Gambar 6.

Pengujian dilakukan pada ketujuh pecahan nominal uang kertas pada setiap muka pada variasi rotasi dengan cara mengubah orientasi default dari akuisisi citra uang 
Tabel 1. Hasil pengujian variasi rotasi dari 7 nominal uang kertas

\begin{tabular}{|c|c|c|c|c|c|}
\hline $\begin{array}{l}\text { Nominal } \\
\text { (rupiah) }\end{array}$ & $\begin{array}{l}\text { Pengujian } \\
\text { (Rotasi) }\end{array}$ & Citra Uji & $\begin{array}{c}\text { Berhasil Dikenali } \\
\text { dengan Benar }\end{array}$ & $\begin{array}{c}\text { Dikenali sebagai } \\
\text { objek lain }\end{array}$ & Akurasi \\
\hline \multirow[t]{4}{*}{1000} & $0^{\circ}$ & 4 & 4 & 0 & $100 \%$ \\
\hline & $90^{\circ}$ & 4 & 4 & 0 & $100 \%$ \\
\hline & $180^{\circ}$ & 4 & 4 & 0 & $100 \%$ \\
\hline & $270^{\circ}$ & 4 & 4 & 0 & $100 \%$ \\
\hline \multirow[t]{4}{*}{2000} & $0^{\circ}$ & 4 & 4 & 0 & $100 \%$ \\
\hline & $90^{\circ}$ & 4 & 4 & 0 & $100 \%$ \\
\hline & $180^{\circ}$ & 4 & 4 & 0 & $100 \%$ \\
\hline & $270^{\circ}$ & 4 & 4 & 0 & $100 \%$ \\
\hline \multirow[t]{4}{*}{5000} & $0^{\circ}$ & 4 & 4 & 0 & $100 \%$ \\
\hline & $90^{\circ}$ & 4 & 4 & 0 & $100 \%$ \\
\hline & $180^{\circ}$ & 4 & 4 & 0 & $100 \%$ \\
\hline & $270^{\circ}$ & 4 & 4 & 0 & $100 \%$ \\
\hline \multirow[t]{4}{*}{10000} & $0^{\circ}$ & 4 & 4 & 0 & $100 \%$ \\
\hline & $90^{\circ}$ & 4 & 4 & 0 & $100 \%$ \\
\hline & $180^{\circ}$ & 4 & 4 & 0 & $100 \%$ \\
\hline & $270^{\circ}$ & 4 & 4 & 0 & $100 \%$ \\
\hline \multirow[t]{4}{*}{20000} & $0^{\circ}$ & 4 & 4 & 0 & $100 \%$ \\
\hline & $90^{\circ}$ & 4 & 4 & 0 & $100 \%$ \\
\hline & $180^{\circ}$ & 4 & 4 & 0 & $100 \%$ \\
\hline & $270^{\circ}$ & 4 & 4 & 0 & $100 \%$ \\
\hline \multirow[t]{4}{*}{50000} & $0^{\circ}$ & 4 & 4 & 0 & $100 \%$ \\
\hline & $90^{\circ}$ & 4 & 4 & 0 & $100 \%$ \\
\hline & $180^{\circ}$ & 4 & 4 & 0 & $100 \%$ \\
\hline & $270^{\circ}$ & 4 & 4 & 0 & $100 \%$ \\
\hline \multirow[t]{4}{*}{100000} & $0^{\circ}$ & 4 & 4 & 0 & $100 \%$ \\
\hline & $90^{\circ}$ & 4 & 4 & 0 & $100 \%$ \\
\hline & $180^{\circ}$ & 4 & 4 & 0 & $100 \%$ \\
\hline & $270^{\circ}$ & 4 & 4 & 0 & $100 \%$ \\
\hline
\end{tabular}

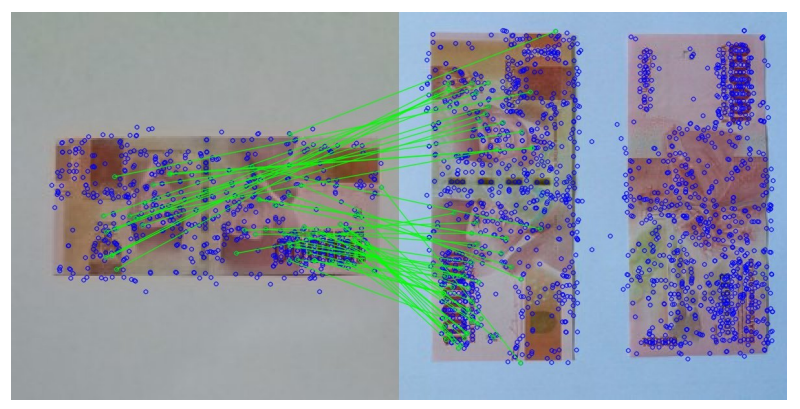

Gambar 6. Proses identifikasi citra nominal uang kertas rupiah dengan metode FLANN

kertas. Variasi rotasi pada akuisisi citra uang kertas terdiri dari tanpa rotasi atau $0^{\circ}$, rotasi $90^{\circ}$, rotasi $180^{\circ}$, dan rotasi $270^{\circ}$. Detail hasil pengujian yang telah dilakukan terhadap citra uang kertas ditunjukkan pada Tabel 1. Akurasi sistem pada pengujian dari variasi rotasi dihitung berdasarkan Persamaan 2. Akurasi klasifikasi untuk semua nominal pecahan uang kertas yang diuji tanpa rotasi $\left(0^{\circ}\right)$ sebesar $100 \%$. Berdasarkan pengujian dengan berbagai variasi rotasi, terlihat bahwa pengujian dari masing-masing pecahan nominal uang kertas rupiah dengan semua variasi rotasi memiliki nilai akurasi sebesar 100\%. Dari hal tersebut, dapat dinyatakan bahwa akurasi total dari metode SURF dan
FLANN untuk identifikasi nominal uang kertas rupiah tahun emisi 2016 menunjukkan nilai akurasi sebesar $100 \%$. Hal ini menunjukkan bahwa metode SURF untuk ekstraksi ciri dan FLANN dalam identifikasi nominal uang kertas rupiah tahun emisi 2016 memiliki ketahanan yang sangat baik terhadap rotasi.

Hasil yang diperoleh dalam penelitian ini mempunyai akurasi yang lebih baik daripada [7] yang menghasilkan akurasi sebesar 50\% menggunakan algoritma Backpropagation Levenberg Marquardt, pada [8] dengan akurasi 90\% menggunakan JST, pada [9] dengan akurasi 93,57\% menggunakan algoritma Convolutional Neural Network MXNET [9]. Namun, pada dasarnya hal ini tidak dapat dibandingkan karena objek, jumlah, dan variasi pengujian sistem dari masingmasing penelitian berbeda.

\section{KESIMPULAN}

Metode SURF dan FLANN dapat digunakan untuk identifikasi nominal uang kertas rupiah tahun emisi 2016 yang terdiri dari pecahan Rp 1.000,00, Rp 2.000,00, Rp 5.000,00, Rp 10.000,00, Rp 20.000,00, Rp 50.000,00 dan Rp 100.000,00. Pendekatan metode SURF untuk ekstraksi ciri dan FLANN untuk feature matching dalam identifikasi uang kertas tersebut dengan tingkat akurasi identifikasi sebesar 100\%.. 


\section{UCAPAN TERIMA KASIH}

Terima kasih disampaikan kepada Fakultas Teknik dan Teknologi Informasi Universitas Jenderal Achmad Yani Yogyakarta yang telah mendukung terlaksananya penelitian ini.

\section{Daftar Pustaka}

[1] S. Haware and A. Barhatte, "Retina Based Biometric Identification using SURF and ORB Feature Descriptors,” in 2017 International Conference on Microelectronic Devices, Circuits And Systems (ICMDCS), Vellore, India, Aug. 2017, pp. 1-6.

[2] J. Farooq, "Object Detection and Identification using SURF and BoW Model," in 2016 International Conference on Computing, Electronic and Electrical Engineering (ICE Cube), Quetta, Pakistan, Apr. 2016, pp. 318-323.

[3] S. Ahmed, T. Gaber, A. Tharwat, A. E. Hassanien, and V. Snael, "Muzzle-Based Cattle Identification Using Speed up Robust Feature Approach,” in 2015 International Conference on Intelligent Networking and Collaborative Systems, Taipei, Taiwan, Sept. 2015, pp. 99-104.

[4] R. A. Yunmar and A. Harjoko, "Sistem Identifikasi Relief pada Situs Bersejarah Menggunakan Perangkat Mobile Android (Studi Kasus Candi Borobudur)," IJCCS (Indonesian Journal of Computin and Cybernetics Systems), vol. 8, no. 2, pp. 133-144, Jul. 2014.

[5] M. B. Ariel, R. D. Atmaja, and A. Azizah, "Implementasi Metode Speed Up Robust Feature dan Scale Invariant Feature Transform untuk Identifikasi Telapak Kaki Individu,” Jurnal Al-
Azhar Indonesesia, vol. 3, no. 4, pp. 178-186, Dec. 2017.

[6] F. F. Adi, M. Ichwan, and Y. Miftahuddin, "Implementasi Algoritma Speeded Up Robust Features (SURF) pada Pengenalan Rambu-Rambu Lalu Lintas," Jurnal Teknik Informatika dan Sistem Informasi, vol. 3, no. 3, Dec. 2017.

[7] H. Hikmayanti and O. Komarudin, "Penggunaan Algoritma Backpropagation Levenberg Marquardt dan Teknik Pengolahan Citra Digital untuk Identifikasi Nominal Uang Kertas,” Jurnal Ilmiah Solusi, vol. 1, no. 2, pp. 16-33, Jul. 2015.

[8] I. G. Saputra, E. Susanto, and R. Nugraha, "Implementasi Metode Jaringan Saraf Tiruan (JST) pada Alat Deteksi Nilai Nominal Uang," eProceedings of Engineering, vol. 3, no. 1, pp. 6571, Apr. 2016.

[9] R. Izah, "Klasifikasi Nominal Uang Kertas Rupiah Tahun Emisi 2017 dengan Algoritma Convolutional Neural Network Menggunakan MXNET,” Skripsi, Universitas Islam Indonesia, 2018.

[10] Z. Hamizan and R. Sumiharto, "Sistem Pentautan Citra Udara Menggunakan Algoritme SURF dan Metode Reduksi Data,” IJEIS (Indonesian Journal of Electronics and Instrumentations Systems, vol. 7, no. 2, pp. 127-138, Oct. 2017.

[11] L. Arsy, O. D. Nurhayati, and K. T. Martono, “Aplikasi Pengolahan Citra Digital Meat Detection dengan Metode Segmentasi K-Mean Clustering Berbasis OpenCV dan Eclipse,” Jurnal Teknologi dan Sistem Komputer, vol. 4, no. 2, p. 322-332, Apr. 2016.

[12] A. Priadana, “Analisis Pengaruh Ukuran Citra Hasil Resizing terhadap Jumlah Keypoint Hasil Ekstraksi Ciri pada Metode SIFT dan SURF," Teknomatika, vol. 11, no. 1, pp. 9-18, Dec. 2018. 